\title{
ANTIOXIDANT AND HEPATOPROTECTIVE EFFECTS OF TRANILAST AGAINST THIOACETAMIDE-INDUCED LIVER FIBROSIS IN RATS
}

\author{
Ramadan A. ${ }^{1}$, Nehal A. Afifi ${ }^{1}$, Nemat Z. Yassin ${ }^{2}$, Rehab F. Abdel-Rahman ${ }^{2}$, Sahar S. Abd \\ El-Rahman ${ }^{3}$ and Hany M. Fayed ${ }^{* 2}$ \\ ${ }^{1}$ Pharmacology Department, Faculty of Veterinary Medicine, Cairo University, Egypt. \\ ${ }^{2}$ Pharmacology Department, Medical Division, National Research Centre, Giza, Egypt. \\ ${ }^{3}$ Pathology Department, Faculty of Veterinary Medicine, Cairo University, Egypt. \\ *Corresponding author: Hany M. Fayed; E-mail: drhany_fayed2000@yahoo.com
}

\begin{abstract}
The aim of the present study was to investigate the potential antioxidant and Hepatoprotective activities of tranilast against TAA-induced liver fibrosis in rats. Methods: Liver fibrosis was induced in rats by intra peritoneal injection of TAA (200 $\mathrm{mg} / \mathrm{kg}$ ) for 6 weeks. Tranilast was administered orally at a dose of 150 and $300 \mathrm{mg} / \mathrm{kg}$ for 6 weeks before induction of liver fibrosis. Results: Injection of TAA induced hepatic fibrosis that was manifested by a significant increase in the activities of aminotransferases and total bilirubin with a significant decrease in total protein and albumin in serum. Liver homogenate of TAA rats had the lower content of reduced glutathione (GSH) and superoxide dismutase (SOD) with increased levels of the hepatic malondialdehyde. Histological data presented marked damage in liver sections of TAA rats. Oral dosing of tranilast for 6 weeks before induction of liver fibrosis reversed these altered parameters near to normal values. These results suggest that tranilast could afford significant protection and antioxidant effect in prevention of liver fibrosis.
\end{abstract}

Keywords:Hepatic fibrosis, Thioacetamide, Tranilast, Liver, Rat.

\section{Original Article:}

DOI:https://dx.doi.org/10.21608/javs.2017.62131

Received: 14 August, 2017.

Accepted: 27 September, 2017.

Published: 04 October, 2017.

This is an open access article under the term of the Creative Commons Attribution 4.0 (CC-BY) International License. To view a copy of this license, visil http://creativecommons.org/licenses/by/4.0/

\section{INTRODUCTION}

Liver fibrosis is defined as the hepatic dynamic response to repeated and chronic liver injury, accompanying the activation of HSCs, the over expression of extracellular matrix (ECM) proteins, ultimately lead to cirrhosis, which is characterized by scar tissue, loss of parenchymal architecture and organ failure (Wang et al. 2016). It is known that various agents, including chronic infection by hepatotropic viruses (hepatitis $\mathrm{B}$ and hepatitis $\mathrm{C}$ viruses), chronic exposure to toxins or drugs (e.g., alcohol abuse), chronic cholestatic diseases and autoimmune chronic hepatitis result in liver damage. When the damage is prolonged, liver fibrosis occurs (Hernandez-Aquino et al. 2017). The liver fibrosis affects more than 100 million people worldwide and represents one of the most common causes of death in adults (Rehman $\boldsymbol{e t}$ al. 2016). In Egypt, up to $85 \%$ of HCV infections persist for life, leading to chronic hepatitis
(Elgharably et al. 2017).

Thioacetamide (TAA) is a thiono-sulphur containing compound that has been used as a fungicide, a curing ingredient, a chemical reagent, a raw medicine, a textile dye, and a finishing auxiliary (Al-Attar et al. 2017). TAA is a model hepatotoxicant and responsible of severe damage of the cells with significant toxic effects on the biosynthesis of macromolecules including proteins and nucleic acid. Its biotransformation to thioacetamide sulfoxide (TAAS) occurs along the cytochrome P-450 (CYP)dependent pathways (Koblihova et al. 2014). Furthermore, different studies showed that the exposure to TAA caused liver injury, fibrosis and cirrhosis in experimental animals. The hepatic toxic chemical TAA has been widely used in the study of the underlying mechanisms of hepatic fibrogenesis and the therapeutic effects of potential antifibrotic drugs (Al-Attar et al. 2016). 
The prevention of liver fibrosis remains a major problem that troubles the medical profession. Therefore, searching for the safe compound with high preventive and/or therapeutic efficacies is urgently needed (Zhao et al. 2017). Tranilast ( $\mathrm{N}-[3,4-$ dimethoxycinnamoyl]-anthranilic acid; Rizaben $\left.{ }^{\circledR}\right)$ is an analog of the amino acid tryptophan, that was originally approved as an anti-allergic drug. Tranilast was originally developed as a mast cell stabilizer, since it exerts inhibitory effects on the release of chemokines (Baba et al. 2016). Tranilast is currently used in the treatment of inflammatory diseases, such as bronchial asthma, atypical dermatitis, allergic conjunctivitis, keloids and hypertrophic scars (Li et al. 2014). it was demonstrated that tranilast suppressed release of profibrotic cytokines from monocytemacrophages in vitro and reduce tubulointerstitial and heart fibrosis in diabetic rat models, highlighting tranilast antifibrotic properties (Swiderski et al. 2014).

Therefore, the current study aimed to investigate the potential hepatoprotective and antioxidant effects of tranilast against liver fibrosis induced by TAA in male rats.

\section{MATERIALS AND METHODS}

\section{Animals}

Twenty eight adult male Wistar rats weighing 150-180 g were utilized in the present study. Standard food pellets and tap water were supplied ad libitum. Animals and food pellets were obtained from the animal house colony of the National Research Centre (NRC, Egypt). the animals were cared for in accordance with the Guide for the Care and Use of Laboratory Animals (1996, published by National Academy Press, 2101 Constitution Ave. NW, Washington, DC 20055, USA) and that their use was reviewed and approved in accordance with ethical rules for standard experimental animal studies and the Medical Research Ethics Committee (MREC) of the NRC.

\section{Drugs and chemicals}

Thioacetamide (TAA) $\left(\mathrm{C}_{2} \mathrm{H}_{5} \mathrm{NS}\right)$ was obtained from El-Gomhouria Company for drug and chemicals, Egypt. Carboxymethyl cellulose sodium $\left(\mathrm{C}_{8} \mathrm{H}_{5} \mathrm{NaO}_{8}\right)$ was purchased from Sigma-Aldrich (Merck Millipore, Darmstadt, Germany). Tranilast $\left(\mathrm{C}_{18} \mathrm{H}_{17} \mathrm{NO}_{5}\right)$ was obtained from Xiamen Kerda trade CO., LTD., Xiamen City, China.

\section{Experimental design}

Rats were randomly allocated into four groups (7 rats each). Group I rats (normal control) received vehicle $(0.5 \% \mathrm{CMC})$. Liver fibrosis was induced in the remaining 3 groups by intraperitoneal injection of TAA at a dose of $200 \mathrm{mg} / \mathrm{kg}$ b.wt for six weeks
(Ftahy et al. 2013). Group II served as (TAA group). Group $I I I$ and $I V$ rats were administered with tranilast at a dose of 150 and $300 \mathrm{mg} / \mathrm{kg} /$ day, respectively, for 6 weeks then given concomitantly with TAA injection (Abdelaziz et al. 2015).

\section{Serum biochemical analysis}

At the end of the experiment (12 weeks), rats were anaesthetized with diethyl ether and blood samples were withdrawn from the retro-orbital venous plexus. Collected blood samples were allowed to stand for 10 $\mathrm{min}$ at room temperature then centrifuged at $4 \mathrm{oC}$ using cooling centrifuge (Laborzentrifugen, 2k15, Sigma, Germany) at 3000 r.p.m for $10 \mathrm{~min}$. Sera were separated for assessment of levels of aspartate aminotransferase (AST) and alanine aminotransferase (ALT), total bilirubin, total protein and albumin using commercially available kits according to the manufacturer's instructions as follows: Alanine Aminotransferase $\quad$ EIAab ${ }^{\circledR} \quad$ kit, Aspartate Aminotransferase EIAab ${ }^{\circledR}$ kit, total bilirubin BioAssay Systems ${ }^{\circledR}$ kit, total protein Sigma-Aldrich ${ }^{\circledR}$ kit, and albumin Biovision ${ }^{\circledR}$ kit.

\section{Hepatic tissue biochemical analysis}

Directly after blood sampling, rats were sacrificed by cervical dislocation under ether anesthesia. Liver tissues were collected, washed in normal saline and then divided into 2 parts. The first part was homogenized using MPW-120 homogenizer (Med instruments, Poland); the homogenate was centrifuged using a cooling centrifuge (Laborzentrifugen, 2k15, Sigma, Germany) at 3000 r.p.m for $10 \mathrm{~min}$. and the supernatant was assessed for hepatic levels of reduced glutathione (GSH) (Ellman 1959), lipid peroxides as malondialdehyde (MDA) (Ruiz-Larrea et al. 1994), and superoxide dismutase (SOD) (Abdel-Rafei et al. 2016). The second part was used for histopathological examination

\section{Histopathological examination}

Tissue specimens were collected from livers of the different experimental groups and were preserved in $10 \%$ buffered neutral formalin. Formalin fixed liver specimens were routinely dehydrated by graded series of alcohol, cleared in xylol and finally embedded in paraffin. Paraffin blocks were serially sectioned at 4-5 um thickness and stained with $\mathrm{H} \& \mathrm{E}$ (Bancroft and Gamble, 2008).

\section{Statistical analysis}

The results were expressed as mean $\pm \mathrm{SE}$ of the mean. Data analysis was achieved by one-way analysis of variance (ANOVA) followed by Tukey's multiple comparison test using software program GraphPad Prism (version 5.00). A value of $\mathrm{P}<0.05$ was considered statistically significant. 


\section{Ramadan, A.et al.}

\section{RESULTS}

\section{Effect on serum biochemical parameters}

The data in table (1) revealed that, after 6 weeks of TAA injection, there was a significant elevation of serum levels of hepatic enzymes (ALT and AST) and total bilirubin with a significant reduction of total protein and albumin levels compared to normal control. In the present study, the reduction in levels of transaminases, total bilirubin and increased levels of total protein and albumin by pre-treatment of rats with tranilast were recorded, compared to TAA control group.

Effect on reduced glutathione (GSH), malondialdehyde (MDA) and superoxide dismutase (SOD) levels in liver homogenate

The results showed that GSH content and SOD activity were significantly reduced and MDA level was significantly increased in TAA induced liver fibrosis rats, compared to normal control. Administration of tranilast for six weeks prior to liver fibrosis induction significantly brought back these oxidative stress markers toward the range of the corresponding normal control values and significantly different from the TAA group as shown in (figures1 $\mathrm{A}, \mathrm{B}, \mathrm{C})$.

\section{Histopathological examination of liver tissues}

In regards to the histopathological examination, different liver sections of negative control rats revealed normal histological hepatic structure (Figure 2 A) while, examination of the livers of TAA rats revealed severe tissue alterations as marked hepatocellular swelling with vacuolar to ballooning degeneration and cytoplasmic reticulation. Some hepatocytes showed karyocytomegaly, others appeared with pyknotic nuclei, while some others appeared necrotic. The portal areas in those livers showed congested blood vessels, hyperplastic bile duct with multiple newly formed bile ductules as well as fibrous proliferation with its extension toward the parenchyma.

The later extension resulted in marked portal to portal fibrosis and pseudolobulation of the hepatic parenchyma. The hepatic cells inside the lobules showed vacuolar degeneration with cytoplasmic reticulation and pyknotic nuclei, many necrotic cells appeared homogenous eosinophilic masses with the appearance of multiple apoptotic bodies (Figure 2, BF). Some livers of tranilast administrated rats showed very fine strands of fibrous tissue extending from the portal areas toward the parenchyma with good protection of the hepatic parenchymal cells as well as marked apoptosis. The portal areas showed mild portal fibrosis, few inflammatory cells with the surrounding many apoptotic cells (Figure 3, A-D).

Table 1: Effect of pretreatment with tranilast (150 and $300 \mathrm{mg} / \mathrm{kg}$ ) for 6 weeks on serum biochemical parameters in control healthy and TAA liver intoxicated rats.

\begin{tabular}{|c|c|c|c|c|}
\hline & $\begin{array}{l}\text { Normal } \\
\text { control }\end{array}$ & $\begin{array}{c}\text { TAA } \\
\text { group }\end{array}$ & $\begin{array}{c}\text { Tranilast } \\
150 \\
\mathrm{mg} / \mathrm{kg}\end{array}$ & $\begin{array}{c}\text { Tranila } \\
\text { st } \\
\mathbf{3 0 0} \\
\mathrm{mg} / \mathrm{kg}\end{array}$ \\
\hline $\begin{array}{l}\text { AST } \\
(\mathrm{U} / \mathrm{L})\end{array}$ & $\begin{array}{c}21.40 \\
\pm \\
1.00^{\mathrm{b}}\end{array}$ & $\begin{array}{c}126.20 \\
\pm \\
4.1^{\mathrm{a}}\end{array}$ & $\begin{array}{c}53.00 \\
\pm \\
2.00^{\mathrm{ab}}\end{array}$ & $\begin{array}{c}36.40 \\
\pm \\
1.00^{\mathrm{ab}}\end{array}$ \\
\hline $\begin{array}{l}\text { ALT } \\
(\mathrm{U} / \mathrm{L})\end{array}$ & $\begin{array}{c}19.40 \\
\pm \\
1.10^{\mathrm{b}}\end{array}$ & $\begin{array}{c}117.10 \\
\pm \\
3.4^{\mathrm{a}}\end{array}$ & $\begin{array}{c}43.10 \\
\pm \\
2.00^{\mathrm{ab}}\end{array}$ & $\begin{array}{c}29.90 \\
\pm \\
0.30^{\mathrm{a} b}\end{array}$ \\
\hline $\begin{array}{l}\text { Total } \\
\text { Bilirubi } \\
\mathbf{n} \\
(\mathrm{mg} / \mathrm{dl})\end{array}$ & $\begin{array}{c}0.29 \\
\pm \\
0.01^{\mathrm{b}}\end{array}$ & $\begin{array}{c}1.85 \\
\pm \\
0.03^{\mathrm{a}}\end{array}$ & $\begin{array}{c}0.87 \\
\pm \\
0.01^{\mathrm{ab}}\end{array}$ & $\begin{array}{c}0.59 \\
\pm \\
0.02^{a_{b}}\end{array}$ \\
\hline $\begin{array}{l}\text { Total } \\
\text { Protein } \\
(\mathrm{g} / \mathrm{dl})\end{array}$ & $\begin{array}{c}7.52 \\
\pm \\
0.16^{\mathrm{b}}\end{array}$ & $\begin{array}{c}5.08 \\
\pm \\
0.07^{\mathrm{a}}\end{array}$ & $\begin{array}{c}6.28 \\
\pm \\
0.08^{\mathrm{ab}}\end{array}$ & $\begin{array}{c}6.80 \\
\pm \\
0.03^{\mathrm{ab}}\end{array}$ \\
\hline $\begin{array}{l}\text { Albumin } \\
(\mathrm{g} / \mathrm{dl})\end{array}$ & $\begin{array}{c}4.79 \\
\pm \\
0.08^{\mathrm{b}}\end{array}$ & $\begin{array}{c}2.19 \\
\pm \\
0.03^{\mathrm{a}}\end{array}$ & $\begin{array}{c}3.34 \\
\pm \\
0.02^{\mathrm{ab}}\end{array}$ & $\begin{array}{c}3.80 \\
\pm \\
0.04^{a_{b}}\end{array}$ \\
\hline
\end{tabular}

$\mathrm{N}=7$; Values are expressed as mean \pm SEM

$\mathrm{a}=$ significant at $\mathrm{P}<0.05$ when compared with control group $\mathrm{b}=$ significant at $\mathrm{P}<0.05$ when compared with TAA group 


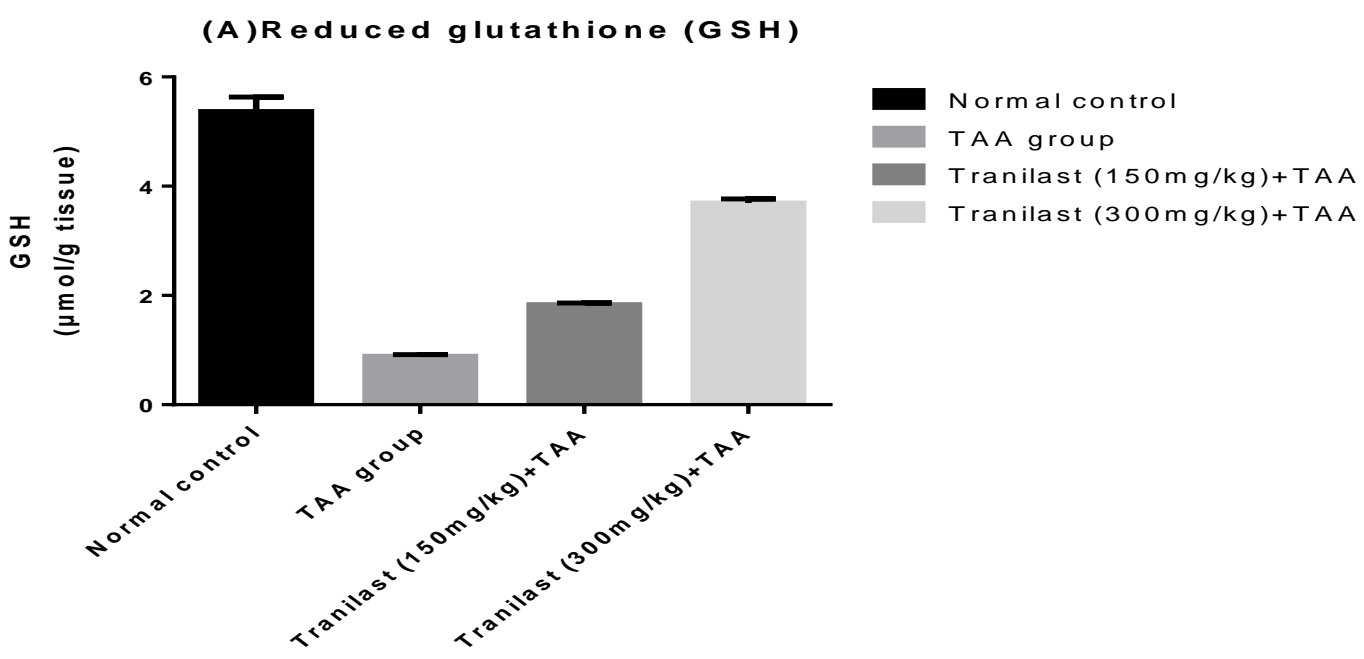

(B) Superoxide dismutase (SOD)

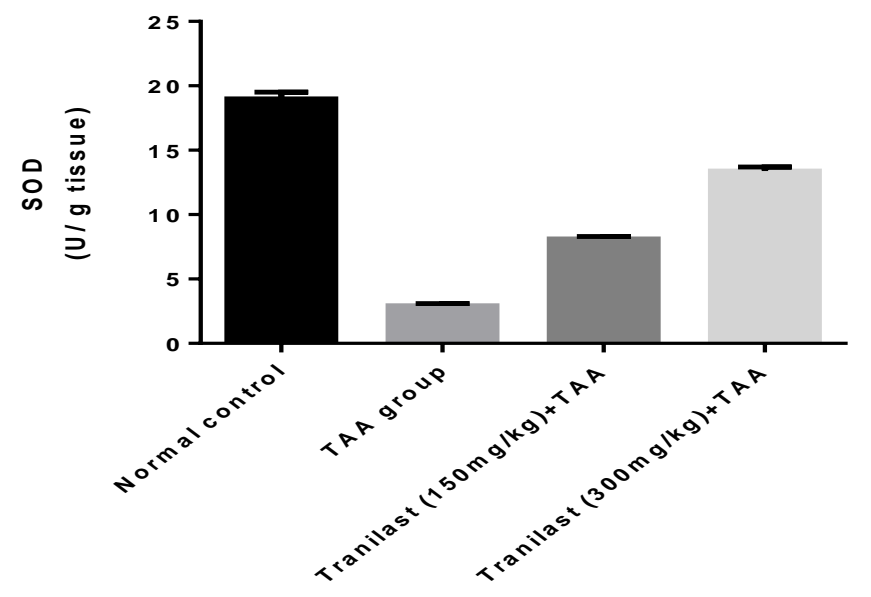

(C) M alondialdehyde (M D A)

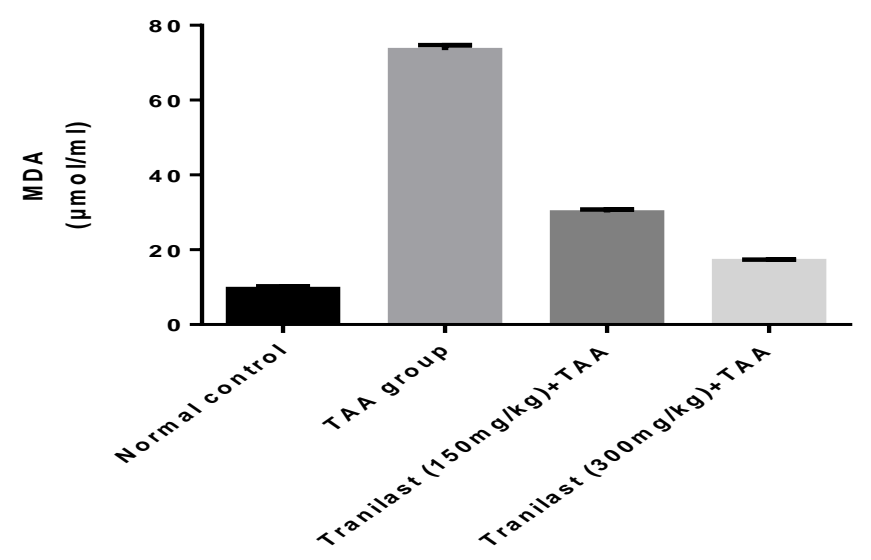

Fig.1. Effect of oral administration of tranilast for 6 weeks before liver fibrosis induction on GSH, SOD and MDA in liver tissue of TAA group. 

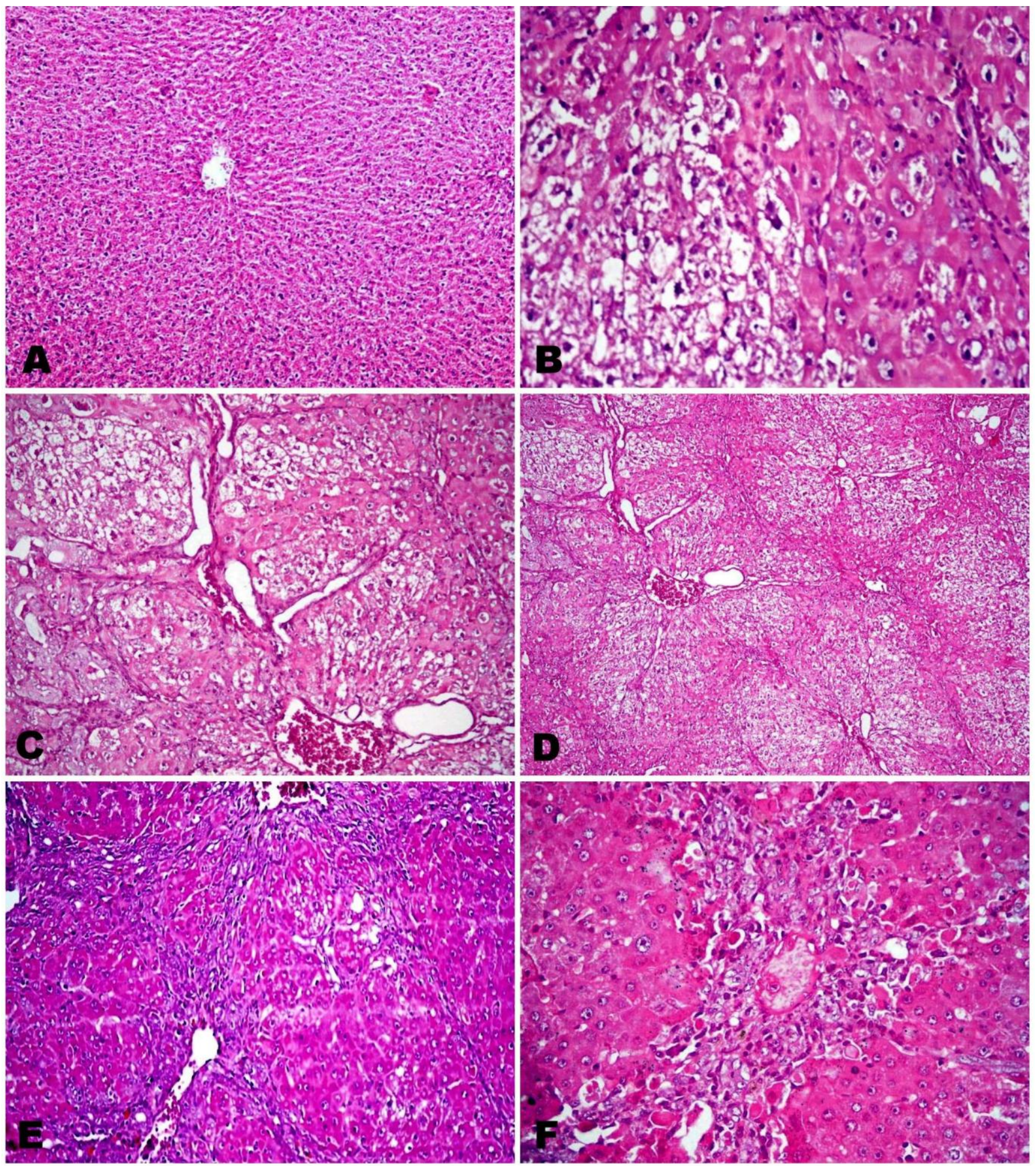

Fig.2. Liver of normal control (A). Liver of thioacetamide administrated rat showing; hepatocellular swelling with vacuolar to ballooning degeneration and cytoplasmic reticulation (B), portal triads showing congested blood vessels, proliferation of bile duct epithelium with multiple newly formed bile ductless as well as fibrous proliferation with its extension peripherally $(\mathrm{C})$, marked portal to portal fibrosis and pseudolobulation (PS) of the hepatic parenchyma (D), many necrotic cells appeared homogenous eosinophilic masses (E), the fibrous septa of the pseudolobulation contained newly formed bile ductules and mononuclear inflammatory cells (F). (H\&E, X400, 200, and 100). 

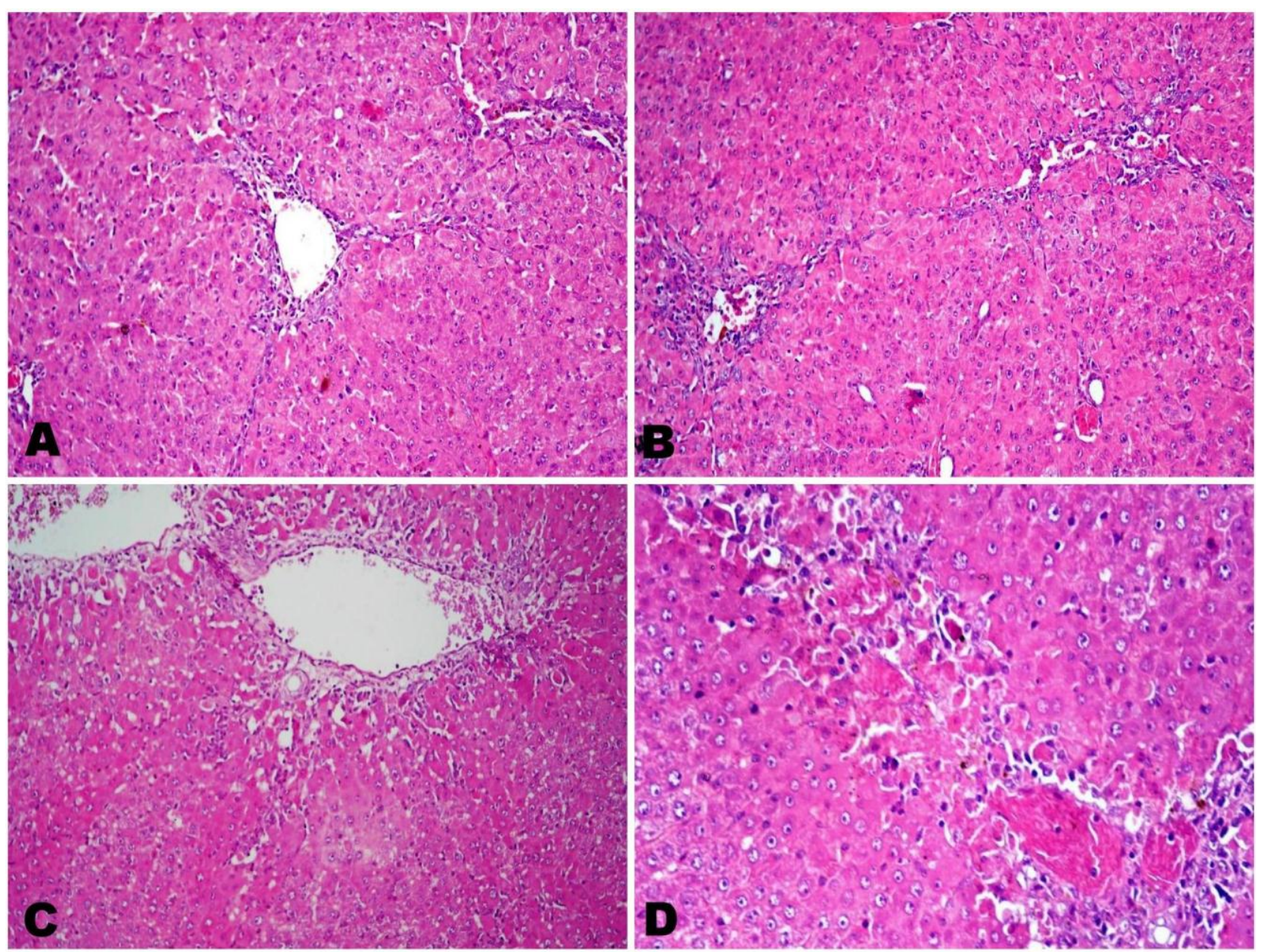

Fig.3. Liver of thioacetamide and tranilast administrated rat showing very fine strands of fibrous tissue (arrow) extending from portal areas toward the parenchyma (A), erasing of fibrotic reaction, near to the normal appearance of the hepatic parenchymal cells, with mild vacuolation (B), portal area of liver of thioacetamide and tranilast administrated rat showing mild portal fibrosis, few inflammatory cells with the surrounding many apoptotic cells $(\mathrm{C})$, good protection of the parenchymal cells with marked apoptosis (D) (H\&E, X400, 200, and 100).

\section{DISCUSSION}

In the current study liver fibrosis was induced by i.p. injection of TAA which significantly impaired hepatic integrity, excretory and synthetic functions, with a significant increase in serum liver enzymes, total bilirubin, hepatic oxidative stress markers as well as a significant decrease in serum total protein, albumin, hepatic GSH content and SOD activity. The aim of this study was to investigate the potential hepatoprotective and antioxidant activities of tranilast on liver fibrosis produced after TAA-administration to male albino Wistar rats.

Results showed that administration of TAA significantly elevated the levels of ALT, AST and total bilirubin, suggesting their leakage from injured hepatocytes into the blood, which agrees with the previously reported results (Develi-Is et al. 2013). The current results showed a significant reduction in serum total protein and albumin levels following TAA injections.

These results were in agreement with (Salama et al. 2013, Hessin et al. 2015). Hypoproteinemia, observed in this study perhaps occur due to inflammatory reaction or might be due to perturbed protein biosynthesis in the cirrhotic liver as demonstrated by (Alshawsh et al. 2011). In the present study, the reduction in levels of transaminases, and total bilirubin while, the increase in total protein and albumin levels by treatment with tranilast is an indication of repair of hepatic tissue damage caused by TAA as reported by (Said $\boldsymbol{e t}$ al. 2012). This was also confirmed by the results of histological examination, as evidenced by a decrease in the incidence and severity of pathological hepatic lesions. 
GSH and SOD are considered as the first line of the cellular antioxidant defense system. In the present study, induction of liver fibrosis through TAA caused marked oxidative stress in rat liver which was evidenced by a significant increase in the content of lipid peroxidation end product, malondialdehyde (MDA) combined with a significant decline in GSH content and SOD activity.

Obtained results are in agreement with those of other studies (Kaur et al. 2017), who reported that low concentration of GSH and SOD has been implicated in TAA induced liver fibrosis. (Chen $\boldsymbol{e t}$ al. 2015) reported that increased level of lipid peroxidation in liver after TAA injection is attributed to free radical-mediated lipid peroxidation, leading to tissue injury, mitochondrial dysfunction, and failure of the antioxidant defense mechanism to prevent the formation of excess free radicals.

In the current study, pretreatment with tranilast for 6 weeks followed by liver fibrosis induction exhibited a protective effect against TAA. This protective effect appeared in the form of significant elevation of liver GSH and SOD with significant depletion of liver MDA compared to TAA group. These results are in agreement with (Said et al. 2016) who found that tranilast administration significantly decreased MDA content in lung and kidney homogenates, suggesting decreased lipid peroxidation, generation of ROS and a positive influence on the host antioxidant defenses. Moreover, (Miyachi et al. 1987) reported that tranilast significantly reduced all ROS levels and this antioxidant effect was related to its ability to scavenge ROS through direct inhibition of nicotinamide adenine dinucleotide phosphate oxidase (NADPH oxidase) and/or xanthine oxidase activity.

\section{CONCLUSION}

The present findings suggest that pre-treatment with tranilast could be more useful for the prevention of hepatic fibrosis induced by TAA in rats.

\section{REFERENCES}

ABDEL-RAFEI, M., AMIN, M.M., HASAN, H.F. 2016. Novel effect of Daflon and low-dose gamma-radiation in modulation of thioacetamide-induced hepatic encephalopathy in male albino rats. Human \& experimental toxicology.

ABDELAZIZ, R.R., ELKASHEF, W.F., SAID, E. 2015. Tranilast reduces serum IL- 6 and IL-13 and protects against thioacetamide-induced acute liver injury and hepatic encephalopathy. Environmental toxicology and pharmacology 40: 259-267.

AL-ATTAR, A.M., ALrOBAI, A.A., ALMALKI, D.A. 2016. Effect of Olea oleaster and Juniperus procera leaves extracts on thioacetamide induced hepatic cirrhosis in male albino mice. Saudi journal of biological sciences 23: 363-371.

Al-AtTAR, A.M., Alrobai A.A., AlmalKi, D.A. 2017. Protective effect of olive and juniper leaves extracts on nephrotoxicity induced by thioacetamide in male mice. Saudi journal of biological sciences 24: 1522.

ALSHAWSH, M.A., ABDULLA, M.A., ISMAIL, S., AMIN, Z.A. 2011. Hepatoprotective Effects of Orthosiphon stamineus Extract on ThioacetamideInduced Liver Cirrhosis in Rats. Evidence-Based Complementary and Alternative Medicine 2011: 6 .

BABA, A., TACHI, M., EJIMA, Y., ENDO, Y., TOYAMA, H., MATSUBARA, M., SAITO, K., YAMAUCHI, M., MIURA, C., KAZAMA, I. 2016. Anti-Allergic Drugs Tranilast and Ketotifen DoseDependently Exert Mast Cell-Stabilizing Properties. Cellular physiology and biochemistry : international journal of experimental cellular physiology, biochemistry, and pharmacology 38: 15-27.

CHEN, CYC., CHIU, P.J., TSENG C.H., YANG, J.K. 2015. Ameliorative effects of D-glucuronolactone on oxidative stress and inflammatory/fibrogenic responses in livers of thioacetamide-treated rats. J Funct Foods 14: 154-162.

DEVELI-IS, S., BEKPINAR, S., KALAZ, E.B., EVRAN, B., UNLUCERCI, Y., GULLUOGLU, M., UYSAL, M. 2013. The protection by heme oxygenase-1 induction against thioacetamide-induced liver toxicity is associated with changes in arginine and asymmetric dimethylarginine. Cell biochemistry and function 31 : 122-128.

ELGHARABLY, A., GOMAA, A.I., CROSSEY, M.M., NORSWORTHY, P.J., WAKED, I., TAYLORROBINSON, S.D. 2017. Hepatitis C in Egypt - past, present, and future. International journal of general medicine 10: 1-6.

ELLMAN, G.L. 1959. Tissue sulfhydryl groups. Archives of biochemistry and biophysics 82: 70-77.

FTAHY, M.M., LATIF N.S.A., ALALKAMY E.F., ELBATRAWI F.A., GALAL A.H., KHATAB, H.M. 2013. Antifibrotic potential of a selective COX-2 inhibitor (celecoxib) on liver fibrosis in rats. Comparative Clinical Pathology 22: 425-430.

HERNANDEZ-AQUINO E. 2017. Naringenin prevents experimental liver fibrosis by blocking TGFbetaSmad3 and JNK-Smad3 pathways. World journal of gastroenterology 23: 4354-4368.

HESSIN, A., HEGAZY, R., HASSAN, A., YASSIN, N., KENAWY, S. 2015. Lactoferrin Enhanced Apoptosis and Protected Against Thioacetamide-Induced Liver Fibrosis in Rats. Open access Macedonian journal of medical sciences 3: 195-201.

KAUR, V., KUMAR M., KAUR P., KAUR S., SINGH, A.P., KAUR, S. 2017. Hepatoprotective activity of Butea monosperma bark against thioacetamideinduced liver injury in rats. Biomedicine \& pharmacotherapy $=$ Biomedecine $\&$ pharmacotherapie 89: 332-341.

KOBLIHOVA, E., MRAZOVA, I., VERNEROVA, Z., RYSKA, M. 2014. Acute liver failure induced by thioacetamide: selection of optimal dosage in Wistar and Lewis rats. Physiological research 63: 491-503. 
LI, S.S., LIU, Q.F., HE, AL., WU, FR. 2014. Tranilast attenuates TGF-beta1-induced epithelial-mesenchymal transition in the NRK-52E cells. Pakistan journal of pharmaceutical sciences 27: 51-55.

MIYACHI, Y., IMAMURA, S., NIWA, Y. 1987. The effect of tranilast of the generation of reactive oxygen species. Journal of pharmacobio-dynamics 10: 255259.

REHMAN, H. 2016. The mitochondria-targeted antioxidant MitoQ attenuates liver fibrosis in mice. International journal of physiology, pathophysiology and pharmacology 8: 14-27.

RUIZ-LARREA, M.B., LEAL AM, LIZA, M., LACORT, M., DE GROOT, H. 1994. Antioxidant effects of estradiol and 2-hydroxyestradiol on ironinduced lipid peroxidation of rat liver microsomes. Steroids 59: 383-388.

SAID, E., ELKASHEF, W.F., ABDELAZIZ, R.R. 2016. Tranilast ameliorates cyclophosphamide-induced lung injury and nephrotoxicity. Canadian journal of physiology and pharmacology 94: 347-358.

SAID, E., SAID, S.A., ELKASHEF, W.F., GAMEIL, N.M., AMMAR, E.M. 2012. Tranilast ameliorates impaired hepatic functions in Schistosoma mansoniinfected mice. Inflammopharmacology 20: 77-87.

SALAMA, SM., ABDULLA, MA., ALRASHDI, A.S., ISMAIL, S., ALKIYUMI, S.S., GOLBABAPOUR, S. 2013. Hepatoprotective effect of ethanolic extract of Curcuma longa on thioacetamide induced liver cirrhosis in rats. BMC complementary and alternative medicine 13: 56.

SWIDERSKI, K., TODOROV, M., GEHRIG, SM., NAIM, T., CHEE, A., STAPLETON, DI., KOOPMAN, R., LYNCH, GS. 2014. Tranilast administration reduces fibrosis and improves fatigue resistance in muscles of $\mathrm{mdx}$ dystrophic mice. Fibrogenesis \& tissue repair 7: 1.

WANG, P., KOYAMA, Y., LIU, X., XU, J., MA, HY., LIANG, S., KIM, IH., BRENNER, D.A., KISSELEVA, T. 2016. Promising Therapy Candidates for Liver Fibrosis. Frontiers in physiology 7: 47.

ZHAO, S., ZHANG, Z., YAO, Z., SHAO, J., CHEN, A., ZHANG, F., ZHENG S. 2017. Tetramethylpyrazine attenuates sinusoidal angiogenesis via inhibition of hedgehog signaling in liver fibrosis. IUBMB life 69: 115-127.
How to cite this article:

Ramadan A., Nehal A. Afifi ${ }^{1}$, Nemat $Z$. Yassin', Rehab F. Abdel-Rahman, Sahar S. Abd El-Rahman and Hany M. Fayed, 2017. Antioxidant and Hepatoprotective Effects of Tranilast Against Thioacetamide-Induced Liver Fibrosis in Rats. Journal of Applied Veterinary Sciences, 5(3): 9 - 16.

DOI: HTTPS://DX.DOI.ORG/10.21608/JAVS.2017.62131 